\title{
Reef sharks and inshore habitats: patterns of occurrence and implications for vulnerability
}

\author{
Andrew Chin ${ }^{1, *}$, Andrew Tobin ${ }^{1}$, Colin Simpfendorfer ${ }^{1}$, Michelle Heupel ${ }^{1,2}$ \\ ${ }^{1}$ Fishing and Fisheries Research Centre, School of Earth and Environmental Sciences, James Cook University, Townsville, \\ Queensland 4811, Australia \\ ${ }^{2}$ Australian Institute of Marine Science, Townsville, Queensland 4810, Australia
}

\begin{abstract}
Reef sharks play important roles in tropical reef environments, but population declines have occurred in various locations including the Great Barrier Reef (GBR). While many reef shark studies focus on coral reefs, some reef sharks have been found across a range of inshore and coastal habitats. This study analyses fisheries observer data across large spatial scales $\left(19314 \mathrm{~km}^{2}\right)$ to investigate the occurrence of reef sharks amongst a mosaic of inshore habitats in the GBR lagoon. Six reef shark species were recorded, but comprised a relatively small proportion $(1.8 \%$ by number) of the elasmobranch catch. The blacktip reef shark dominated the catch of reef sharks $(60.2 \%$ by number), with lemon sharks, zebra sharks, grey carpet sharks, whitetip reef sharks and grey reef sharks less frequently encountered. Reef sharks occur in several habitat types, and logistic regression models suggest that they are most likely to occur in reef habitats and shallow shore habitats. The presence of a reef within $2 \mathrm{~km}$ increased the encounter probability in all habitat types. While the use of these different habitats by reef sharks is not well understood, these habitat use patterns affect the exposure of these species to risks, including some risk factors not considered previously, and could also lead to cumulative impacts. These habitats may also perform important ecological functions in sustaining reef shark populations. Habitat use patterns should be considered in risk assessments and management and have important implications for method selection and survey design in field studies of reef sharks and other mobile reef species.
\end{abstract}

KEY WORDS: Habitat use · Vulnerability · Cumulative impact · Reef shark · Great Barrier Reef · Coastal habitat

Resale or republication not permitted without written consent of the publisher

\section{INTRODUCTION}

The world's coral reefs support a diverse group of chondrichthyan fishes (henceforth referred to as reef sharks), ranging from large, mobile species up to $3 \mathrm{~m}$ in length (e.g. the lemon shark Negaprion acutidens), to small, cryptic reef species (e.g. the epaulette shark Hemiscyllium ocellatum). Reef sharks are generally considered to be high order predators in reef ecosystems where they may exert 'top-down' control of food webs (Stevens et al. 2000, Heithaus et al. 2008). In economic terms, reef sharks are an important source of income as a living attraction for dive tourism (Anderson 2002, Clua et al. 2011, Fitzpatrick et al. 2011), and they contribute to subsistence and commercial fisheries throughout the tropics (Barnett 1996, Teh et al. 2007, White \& Kyne 2010). However, many sharks are long-lived, slow growing species with relatively low reproductive rates (Cortés 2000), traits which increase their vulnerability, particularly to fishing. There are numerous examples of shark populations that have experienced over-exploitation and collapse due to fishing (Simpfendorfer 2000, Graham et al. 2001, Fowler et al. 2005, Dulvy et al. 2008, White \& Kyne 2010), and there is growing concern over the status of sharks on coral reefs (Jackson et al. 2001, Pandolfi et al. 2003). Recent studies suggest reef shark declines in the main Hawaiian Islands 
and the Line Islands in the Pacific (Friedlander \& DeMartini 2002, Stevenson et al. 2007), the Indian Ocean (Graham et al. 2010), and the Great Barrier Reef (GBR) (Robbins 2006, Heupel et al. 2009). There are also anecdotal reports of declines in reef shark populations on coral reefs around numerous Pacific islands (Chin et al. 2011). These concerns have given rise to numerous shark risk assessments, ranging from global (Fowler et al. 2005) to topical assessments for specific fisheries (Salini et al. 2007, Tobin et al. 2010) and climate change (Chin et al. 2010).

The distribution and habitat use patterns of reef sharks need to be considered in risk assessments, in planning conservation and management responses, and in sampling design for reef shark studies. Many tropical elasmobranchs, including reef sharks, have complex movement patterns across a range of spatial and temporal scales, which may include use of a range of habitat types and seasonal aggregations (White \& Sommerville 2010). These spatial use patterns affect the vulnerability of reef sharks to pressures such as fisheries and climate change (Chin et al. 2010). Complex habitat use patterns may also produce skewed data in studies that do not consider these issues. For example, population structuring of blacktip reef sharks Carcharhinus melanopterus, as evident in some locations (Papastamatiou et al. 2009a), could lead to sample bias in studies that only sampled those areas. Habitat use patterns are also important in risk assessments when defining groups or species assemblages. For example, previous studies have defined reef sharks as those species thought to depend on coral reef environments (Chin et al. 2010) or those listed as occurring in coral reef habitats according to species lists and catalogues (WardPaige et al. 2010b).

Relatively little is known about the habitat use of reef sharks, and the current understanding of reef shark habitat use may be limited by constraints such as the limits of SCUBA-based surveys (Ward-Paige et al. 2010a) and difficulties in tracking large, highly mobile species over extended periods. Research using long-term automated acoustic telemetry has revealed complex patterns of habitat use for some other shark species (Simpfendorfer \& Heupel 2004). However, such studies on reef sharks are few and have only recently begun (e.g. Heupel et al. 2010, Papastamatiou et al. 2010, Field et al. 2011, Fitzpatrick et al. 2011). These studies reveal that some reef sharks exhibit highly complex patterns of habitat use and that some species also utilise non-reef environments, such as sandy and muddy foreshores, mangroves, and estuaries (DeAngelis et al. 2008), and may traverse deep-water habitats between reefs (Chapman et al. 2005, Heupel et al. 2010).

In the Great Barrier Reef World Heritage Area (GBRWHA), 19 elasmobranchs have been categorised as reef sharks (Supplement at www.int-res.com/ articles/suppl/m460p115_supp.xlsx). While the GBR is arguably best recognised for its coral reef habitats, these comprise only 5 to $6 \%$ of the GBRWHA (GBRMPA 2009, Pitcher et al. 2009). Much of the remaining area is referred to as the GBR 'lagoon', an area comprised of the shallow waters of the continental shelf between the Queensland coast and the offshore barrier reefs (Pitcher et al. 2009). This lagoon contains a wide range of 'inshore habitats', so called because they lie inshore of the midshelf and outer reefs that form the barrier reef. This mosaic of interconnected habitats includes mangroves, seagrasses, inshore reefs and shoals, and open water with a range of sediment types (Pitcher et al. 2009). Some reef sharks have been recorded in a range of inshore habitat types across the GBRWHA (Salini et al. 2007), suggesting movements beyond coral reef environments. Reef sharks in the GBRWHA face a number of pressures, including habitat degradation and fishing (GBRMPA 2009). The degradation of coral reef habitats through pressures such as climate change may have significant effects on GBR reef sharks (Chin et al. 2010), and the GBR Coral Reef Line Fishery has recorded a significant take of reef sharks, leading to declines of some species (Robbins et al. 2006, Heupel et al. 2009). Additionally, some reef sharks are also taken in the GBR net fishery (Salini et al. 2007, Harry et al. 2011). The GBR net fishery takes the majority of sharks in the GBR, accounting for $>90 \%$ of the annual harvest of sharks in the GBRWHA (Queensland Department of Primary Industries \& Fisheries 2010). The net fishery operates across the GBR lagoon in a wide range of habitats ranging from coastal rivers and estuaries to relatively deep and open waters (to $50 \mathrm{~m}$ depth). While net fishers generally avoid coral reef habitats, reef sharks are caught by net fishers but there are few data about species taken and catch rates. Managers in the GBR have expressed increasing concerns about GBR sharks, citing evidence of reef shark declines, increasing threats from fishing and habitat loss and degradation, and concern over the potential ecological impacts of declines in top predators on GBR reefs (GBRMPA 2009). Here we analysed fishery observer data from the GBR net fishery to quantify the catch of reef sharks in the largest shark fishery in the GBRWHA. These data were used to (1) examine the distribution of reef sharks across a range of habitats in 
the GBR lagoon, (2) investigate the exposure of reef sharks to different risks throughout the GBR, and (3) explore the implications of these patterns of distribution, habitat use and risk exposure for research and management of reef sharks.

\section{MATERIALS AND METHODS}

\section{Study area and observer data}

This study used fishery observer data from the GBR net fishery to investigate the catch and occurrence of reef sharks within the GBR lagoon. This region included all tidal waters along the Queensland east coast stretching eastward of $142^{\circ} 09^{\prime} \mathrm{E}$ near Crab Island $\left(\sim 11.0^{\circ} \mathrm{S}\right)$ southwards to Baffle Creek $\left(\sim 24^{\circ}\right.$
29' S) (Fig. 1). Fishing activity and resulting catch were recorded in situ by independent observers, with each deployment of a net comprising an independent sample. Nets used in foreshore and offshore waters were mostly monofilament mesh, ranging from 115 to $165 \mathrm{~mm}$ mesh size, to target both teleosts and sharks, and 300 to $600 \mathrm{~m}$ in length. For each net sample, observers recorded the catch of each species, fate of captured individuals, length, and sex. Observers also recorded the location of each net sample, using GPS.

Participation by commercial fishers was voluntary with 28 boats participating, ranging from small dinghies $(<5 \mathrm{~m})$ with hand-hauled nets to larger vessels (up to $16 \mathrm{~m}$ long) with hydraulic net-hauling apparatus. This represented a cross section of the type of fishing operations in the fishery, extending across all seasons and a variety of habitats, between 2006 and 2009. A detailed account of the observer program and operational characteristics of the fishery is given in Harry et al. (2011).

\section{Occurrence of reef sharks amongst GBR lagoon habitats}

Observer data were examined to quantify the occurrence of reef sharks in net samples $(\mathrm{n}=1188)$. In this study, the 'reef sharks' were considered as any of the 19 sharks and rays identified as reef sharks in Chin et al. (2010), which classified reef sharks as species that primarily occurred in reef habitats and had an implied dependency on coral reefs. The GBR lagoon included all areas and inshore habitats lying between the Queensland coast and the midshelf reefs of the barrier reef. The distribution of reef sharks amongst the different inshore habitats of the GBR lagoon was analysed by examining presence/absence of reef sharks in a restricted set of net samples $(\mathrm{n}=328)$. The restricted set included every sample that recorded the presence of a reef shark and all adjacent samples within a $40 \mathrm{~km}$ radius of these sample points. The $40 \mathrm{~km}$ radius reflected the distance between the coast and the barrier reef in the central GBR region, and including all samples within this radius
Fig. 1. Delineation of the Great Barrier Reef World Heritage Area (GBRWHA) fishery along the Queensland east coast showing areas of peak shark catch. The black lines indicate the 2 areas used for spatial analysis of reef shark occurrence amongst the different habitats of the GBR lagoon 
ensured that presence/absence data for reef sharks were collected from all available samples across all habitat types. This restricted dataset included many samples where reef sharks were not caught (zero data) and thus facilitated comparison of presence and absence between different habitat types. Samples in the restricted dataset fell into 2 cross-shelf transects that corresponded to the areas of highest shark catch in the GBRWHA (Fig. 1). The first transect covered $10443 \mathrm{~km}^{2}$ of inshore habitat, with the northern boundary stretching from Stephens Island $\left(17^{\circ} 43.63^{\prime} \mathrm{S}\right.$, $146^{\circ} 9.92^{\prime}$ E) to Ellison Reef ( $\left.17^{\circ} 44.43^{\prime} \mathrm{S}, 146^{\circ} 22.59^{\prime} \mathrm{E}\right)$ and a southern boundary stretching from the Haughton River mouth $\left(19^{\circ} 23.97^{\prime} \mathrm{S}, 147^{\circ} 7.97^{\prime} \mathrm{E}\right)$ to Keeper Reef $\left(18^{\circ} 45.16^{\prime} \mathrm{S}, 147^{\circ} 15.77^{\prime} \mathrm{E}\right)$ (Fig. 1). The second transect covered $8871 \mathrm{~km}^{2}$ of inshore habitat, with a northern boundary stretching from Cape Edgecomb $\left(19^{\circ} 58.35^{\prime} \mathrm{S}, 148^{\circ} 15.65^{\prime} \mathrm{E}\right)$ to Gould Reef No. 3 $\left(19^{\circ} 31.86^{\prime} \mathrm{S}, 148^{\circ} 44.17^{\prime} \mathrm{E}\right)$ and a southern boundary stretching from South Repulse Reef $\left(20^{\circ} 37.07^{\prime} \mathrm{S}\right.$, $\left.148^{\circ} 52.33^{\prime} \mathrm{E}\right)$ to Round Reef ( $\left.19^{\circ} 58.07^{\prime} \mathrm{S}, 149^{\circ} 37.18^{\prime} \mathrm{E}\right)$. No reef sharks were recorded outside these regions.

To investigate the effect of in situ habitat type on the occurrence of reef sharks, the habitat type of each of the 328 samples was assigned using a range of spatial data and mapping tools. The position of each sample was plotted on Google Earth (WGS84 datum), and mapping accuracy was determined as being within $10 \mathrm{~m}$ through validation using 11 ground control points, including a fixed geo-reference site established by Geosciences Australia. Once plotted, the habitat type of each sample was qualitatively determined by assessing information from satellite imagery (QuickBird and Google Earth), spatial datasets and maps from the Great Barrier Reef Marine Park Authority and the Queensland Government's Coastal Habitat Resources Information System, bathymetry, local expert knowledge from commercial fishers, and substrate composition data compiled from 135 sampling locations from the Seabed Biodiversity Project (Pitcher et al. 2009). This process identified 6 habitat types which were used to assign a habitat type for each net sample (Table 1).

The presence of biological features in the vicinity of the sample location may also influence the occurrence of reef sharks in a sample. To account for these effects, the proximity of each net sample to 3 key biological features was recorded: (1) inshore reefs, (2) mangroves, and (3) seagrass meadows. Proximity was defined as a sample located within $2 \mathrm{~km}$ of one or more of these biological features. The $2 \mathrm{~km}$ criterion was based on information about reef shark movement distances recorded on coral reef atolls (Stevens 1984, Papastamatiou et al. 2009a, Papastamatiou et al. 2009b). The spatial data sources previously mentioned were used to identify the presence of these biological features and distance to net samples. Additional data used for this analysis included seagrass distribution models (Coles et al. 2009, Grech $\&$ Coles 2010), seagrass monitoring data from Seagrass Watch (Mellors et al. 2008), and reef extent data from the Great Barrier Reef Marine Park Authority. Seagrasses, reefs, and mangroves were selected a priori as key biological features because they are significant features for a number of species, including reef sharks (Stevens 1984, White \& Potter 2004, Knip et al. 2010, White \& Sommerville 2010), and could be mapped using the data available.

\section{Habitat type and reef shark distribution}

Once in situ habitat type and proximity data were collated, the effect of habitat type and proximity to key biological features on the probability of capturing a reef shark in a net sample (encounter probability) was explored using logistic regression generalised linear models (GLM). This approach is well

Table 1. Information from the Seabed Biodiversity Project, maps, online datasets, satellite imagery, and expert knowledge revealed 6 broad habitat categories ranging from estuaries to deeper water habitats of varying substrate types

\begin{tabular}{|c|c|c|}
\hline Habitat types & Description & $\begin{array}{l}\text { No. of net samples } \\
\text { per habitat type } \\
\text { (total 328) }\end{array}$ \\
\hline River/estuary & Habitats within coastal rivers and estuaries that remain submerged at low the tide & 6 \\
\hline Shore & $\begin{array}{l}\text { Inter-tidal and sub-tidal habitats including sandy, muddy and rocky substrates along } \\
\text { beaches and coastal foreshores }\end{array}$ & 173 \\
\hline Reef & Inshore coral reefs and shoals with living hard and soft corals & 12 \\
\hline Muddy open & Deeper water habitats $>2 \mathrm{~m}$ depth (low water) with mud or silt substrate & 123 \\
\hline Sandy open & Deeper water habitats $>2 \mathrm{~m}$ depth (low water) with sandy to gravel and rock substrate & 3 \\
\hline Rocky open & Deeper water habitats $>2 \mathrm{~m}$ depth (low water) with gravel to rocky substrate & 11 \\
\hline
\end{tabular}


suited to modeling uneven, zero-inflated datasets (data with a high proportion of zero data), which violate many of the assumptions of normal statistical tests and modeling approaches (Mayer et al. 2005). In this study, logistic GLMs were used to examine the relationship between the presence/absence of reef sharks (the outcome variable) and in situ habitat type and proximity to biological features (predictor variables). Specifically, logistic GLMs tested the effects of 4 factors: (1) in situ habitat type, (2) proximity to inshore reefs, (3) proximity to mangroves, and (4) proximity to seagrasses. Models were run to explore trends for (1) all reef sharks (data pooled for all reef shark species) and for (2) individual species in order to investigate species-specific patterns of occurrence. However, only the blacktip reef shark had sufficient data to explore species-specific patterns. In both cases, models were run for each of the 16 possible combinations of these 4 factors and for a 'null model' which modeled reef shark presence/absence without any of these factors. Akaike information criteria (AIC weights) (Burnham \& Anderson 2002) were used to select the best models and indicated the combinations of predictor variables (habitat types and proximity to key biological features) that best explained the presence of reef sharks. The coefficients of the best models were used to derive odds ratios which described the relative probabilities of encountering a reef shark between habitat types and key biological features. Models were run in Program R (R Development Core Team 2010).
6 species $(n=123)$ equalling $1.8 \%$ of the total number of sharks and rays recorded in the catch $(\mathrm{n}=$ 6828). Size data for the blacktip reef shark showed that the majority of sharks captured were juvenile sharks of both sexes (Fig. 3).

Reef sharks were captured in 38 of the 328 samples in the restricted dataset, with 7 of these samples capturing 2 reef shark species. Sampling data show that reef sharks were encountered in a variety of habitats, and suggest some interspecific differences in habitat

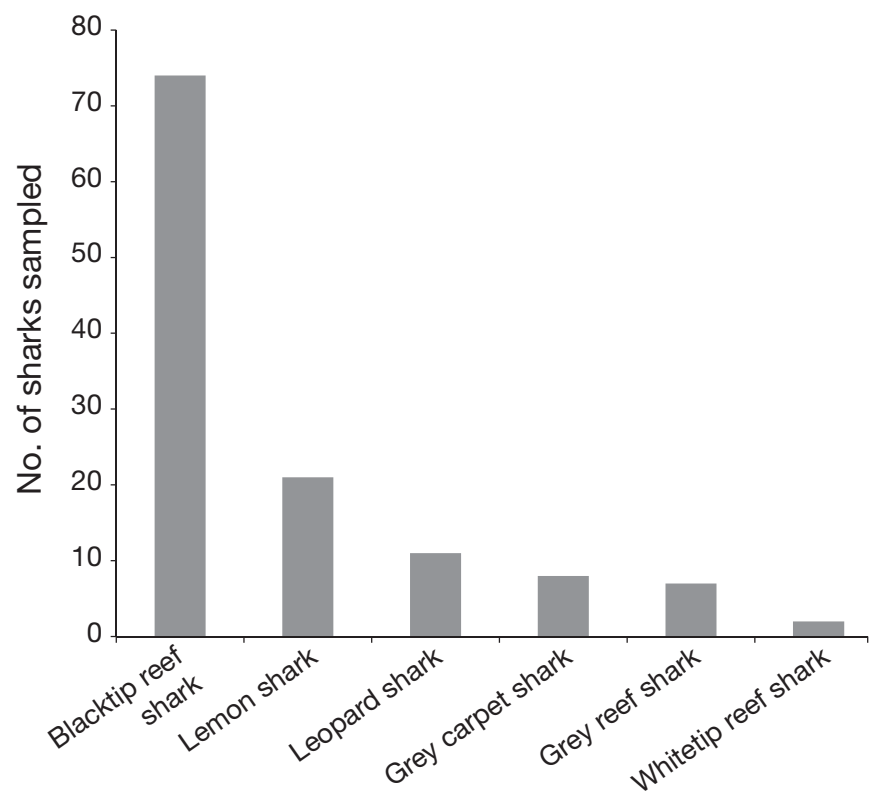

Fig. 2. Species composition of the reef sharks sampled in inshore habitats in the Great Barrier Reef (GBR) lagoon

\section{RESULTS}

Six of the 19 species of reef shark reported by Chris et al. (2010) were encountered in inshore habitats (Fig. 2). The blacktip reef shark Carcharhinus melanopterus represented the majority $(60.2 \%)$ of the reef shark catch, with less frequently encountered reef sharks including (in descending order) the lemon shark Negaprion acutidens, zebra shark Stegostoma fasciatum, grey reef shark Carcharhinus amblyrhynchos, grey carpet shark Chiloscyllium punctatum, and whitetip reef shark Triaenodon obesus (Fig. 2). Reef sharks comprised only a small component of the total shark catch in the GBR net fishery, with the combined catch of these

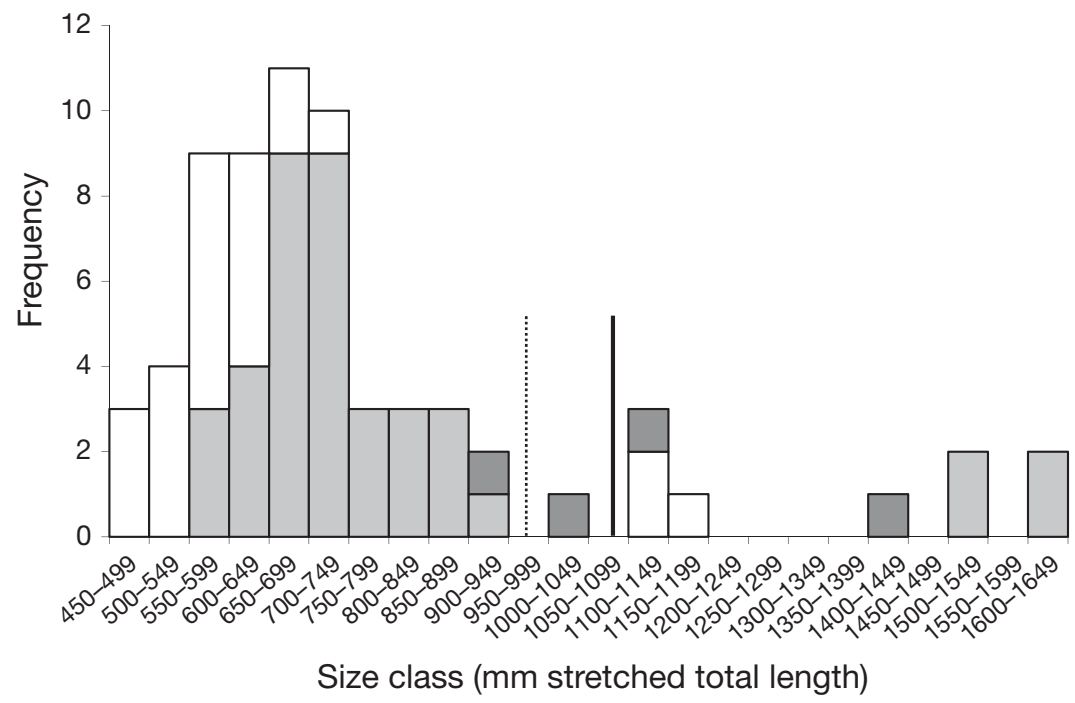

Fig. 3. Size frequency distribution of male (white), female (light grey) and unsexed (dark grey) blacktip reef sharks $(n=67)$ observed from the GBR coastal net fishery. Size at maturity for males (Chin unpubl. data; dashed line) and females (Lyle (1987); solid line) shown 
use. Grey reef and whitetip reef sharks were only observed in samples where the in situ habitat type was reef, while observations of other species occurred predominantly in non-reef habitats (Table 2). However, most reefs sharks were caught within $2 \mathrm{~km}$ of a reef, suggesting that reef proximity was an important factor in encountering reef sharks. The only exception was the zebra shark which mostly occurred in locations $>2 \mathrm{~km}$ away from the nearest reef (Table 2).

Logistic GLMs revealed that in situ habitat type and proximity to reefs significantly affected the probability of encountering a reef shark. Of all the models tested, the 2 factor GLM that modelled the factors 'in situ habitat type' + 'proximity to reefs' had the highest AIC weight (0.36), meaning that this was the best supported model (Table 3) and that these 2 factors were the most significant in explaining the observed distribution of reef sharks. The 2 next best models which received moderate support from the data included the factors 'proximity to mangroves' or 'proximity to seagrass' (i.e. 3 factor models) (Table 3 ). The odds ratios for the best supported model indicated that reef sharks were most likely to be encountered in reef and shore habitats (Table 4) compared to other habitat types, and especially when reefs were located close by. Compared to the modelled reference point, 'river/ estuary' (automatically selected by $\mathrm{R}$ during the analysis), reef sharks were $361 \%$ more likely to be encountered in a location within $2 \mathrm{~km}$ of a reef, $14 \%$ more likely to be encountered in shore habitats, and $7 \%$ more likely to be encountered in open water muddy substrate habitats. The significance of open water muddy substrate habitats may be driven by the zebra shark as this species was most often encountered in these habitats (Table 2). Proximity to mangroves and seagrasses also appeared to increase the probability of encountering a reef shark, as models that included these factors in addition to habitat type and proximity to reefs were the next 2 best models according to AIC weights (Table 3 ).

Only the blacktip reef shark had a sufficient number of capture events to examine species-specific spatial patterns. Similar to the analysis for all reef

Table 3. Akaike Information Criterion (AIC) model selection showing the 3 best models that explain the occurrence of all reef sharks, and the best 3 models that explain the occurrence of blacktip reef sharks. These models had the greatest support as indicated by having the highest AIC weights. The model for in situ habitat type + reef proximity best explained the occurrence of all reef sharks (catches of all species combined) and for the blacktip reef shark

\begin{tabular}{|c|c|c|c|c|}
\hline Model structure & $\begin{array}{l}\text { Degrees of } \\
\text { freedom }\end{array}$ & $\begin{array}{c}\text { AIC } \\
\text { value }\end{array}$ & $\Delta \mathrm{AIC}$ & $\begin{array}{c}\text { AIC } \\
\text { weight }\end{array}$ \\
\hline $\begin{array}{l}\text { All reef sharks combined } \\
\text { Two factor model: }\end{array}$ & & & & \\
\hline Habitat type + reef proximity & 7 & 226.17 & 0.00 & 0.36 \\
\hline $\begin{array}{l}\text { Three factor model: } \\
\text { Habitat type + reef proximity }+ \\
\text { mangrove proximity }\end{array}$ & 8 & 227.38 & 1.21 & 0.19 \\
\hline $\begin{array}{l}\text { Three factor model: } \\
\text { Habitat type + reef proximity }+ \\
\text { seagrass proximity }\end{array}$ & 8 & 228.17 & 2.00 & 0.13 \\
\hline $\begin{array}{l}\text { Blacktip reef shark } \\
\text { Two factor model: }\end{array}$ & & & & \\
\hline Habitat type + reef proximity & 7 & 123.36 & 0.00 & 0.44 \\
\hline $\begin{array}{l}\text { Three factor model: } \\
\text { Habitat type + reef proximity }+ \\
\text { seagrass proximity }\end{array}$ & 8 & 125.29 & 1.92 & 0.17 \\
\hline $\begin{array}{l}\text { Three factor model: } \\
\text { Habitat type + reef proximity }+ \\
\text { mangrove proximity }\end{array}$ & 8 & 125.36 & 2.00 & 0.16 \\
\hline
\end{tabular}

Table 2. The percentage of the catch (calculated from the numbers of reef sharks caught) of reef sharks amongst different habitat types in the GBR lagoon, and in proximity to inshore reefs

Blacktip reef shark Lemon shark Zebra shark Grey reef shark Grey carpet shark Whitetip reef shark

\begin{tabular}{lcccccc}
\hline Habitat type & \% Catch per habitat type & & & \\
River/estuary & 0 & 25 & 0 & 0 & 67 & 0 \\
Shore & 93 & 75 & 14 & 0 & 0 & 100 \\
Inshore reef & 7 & 0 & 0 & 100 & 33 & 0 \\
Muddy open & 0 & 0 & 86 & 0 & 0 & 0 \\
Sandy open & 0 & 0 & 0 & 0 & 0 & 0 \\
Rocky open & 0 & 0 & 0 & & 66 \\
Inshore reef & \% Catch with proximity to an inshore coral reef & & \\
within 2 km & 98 & 75 & 25 & 100 & 100 \\
\hline
\end{tabular}


Table 4. Results of the logistic regression generalised linear models for the best fitting model for 'all reef sharks combined', and for the 'blacktip reef shark'. ${ }^{*} \mathrm{p}<0.01,{ }^{* *} \mathrm{p}<0.001$

\begin{tabular}{|c|c|c|c|c|c|}
\hline Predictor variables & Estimate & $\mathrm{SE}$ & $\begin{array}{c}Z \text {-value } \\
\text { (Wald statistic) }\end{array}$ & $\mathrm{p}$ & Odds ratios \\
\hline $\begin{array}{l}\text { All reef sharks combined } \\
\text { Intercept (Habitat type = } \\
\text { river/estuary) }\end{array}$ & -0.6931 & 0.8660 & -0.800 & 0.42349 & ${ }^{\mathrm{a}} 0.500000$ \\
\hline Habitat type $=$ reef & -1.2857 & 1.1386 & -1.129 & 0.25884 & 0.276468 \\
\hline $\begin{array}{l}\text { Habitat type }= \\
\text { open water muddy substrate }\end{array}$ & -2.5730 & 0.9777 & -2.632 & $0.00850^{* *}$ & 0.076309 \\
\hline $\begin{array}{l}\text { Habitat type }= \\
\text { open water rocky substrate }\end{array}$ & -17.9885 & 1175.6370 & -0.015 & 0.98779 & $1.540629 \times 10^{-8}$ \\
\hline $\begin{array}{l}\text { Habitat type }= \\
\text { open water sandy substrate }\end{array}$ & -17.8345 & 2229.8561 & -0.008 & 0.99362 & $1.797074 \times 10^{-8}$ \\
\hline Habitat type = shore & -1.9188 & 0.9398 & -2.042 & $0.04118^{*}$ & 0.146788 \\
\hline Proximity to reef & 1.2857 & 0.4141 & 3.105 & $0.00190^{* *}$ & 3.617049 \\
\hline $\begin{array}{l}\text { Blacktip reef shark } \\
\text { Intercept (Habitat type = } \\
\text { river/estuary) }\end{array}$ & -20.566 & 7238.393 & -0.003 & 0.99773 & $\mathrm{a} 1.170227 \times 10^{-9}$ \\
\hline Habitat type $=$ reef & 16.155 & 7238.393 & 0.002 & 0.99822 & $1.037966 \times 10^{7}$ \\
\hline $\begin{array}{l}\text { Habitat type }= \\
\text { open water - muddy substrate }\end{array}$ & -2.324 & 7382.433 & -0.000315 & 0.99975 & 0.097919 \\
\hline $\begin{array}{l}\text { Habitat type }= \\
\text { open water - rocky substrate }\end{array}$ & 3.054 & 8896.528 & -0.000343 & 0.99973 & 0.047193 \\
\hline $\begin{array}{l}\text { Habitat type }= \\
\text { open water - sandy substrate }\end{array}$ & -2.806 & 12058.703 & -0.000233 & 0.99981 & 0.060475 \\
\hline Habitat type shore & 16.033 & 7238.393 & 0.002 & 0.99823 & $9.188553 \times 10^{6}$ \\
\hline Proximity to reef & 3.312 & 1.041 & 3.183 & $0.00146^{* *}$ & 27.4426 \\
\hline
\end{tabular}

shark data combined, GLM models showed the importance of habitat type and proximity to reefs in capturing blacktip reef sharks. The 2 factor GLM that modelled the factors 'in situ habitat type' and 'proximity to reefs' had the largest support from the data (AIC weight $=0.44$ ), while the models that also included mangrove proximity or seagrass proximity also had moderate support (Table 3). The odds ratios for the best-supported model indicated that, compared to the reference point (river/estuary), blacktip reef sharks were 27 times more likely to be found in locations within $2 \mathrm{~km}$ of a reef (Table 4 ). The odds ratios also suggested that compared to the reference point, samples set in locations where the in situ habitat type was 'shore' or 'reef' were over a million times more likely to result in capture of blacktip reef sharks. However, these predictor variables had high standard errors (Table 4) and thus need to be treated with caution. Similar to the data for all reef sharks combined, the presence of mangroves and seagrasses within $2 \mathrm{~km}$ of a sample may also increase the probability of capturing a blacktip reef shark.

\section{DISCUSSION}

This study reveals that several reef shark species occur in a variety of inshore habitats in the GBR lagoon, particularly shallow intertidal and subtidal habitats and, for species such as the zebra shark, open water muddy substrate habitats. The proximity of mangroves and seagrasses also increase reef shark encounter probabilities. These findings add to previous accounts of habitat associations or classification systems where species such as the zebra shark and blacktip reef sharks were classified as 'reef sharks' because they primarily inhabit coral reefs (e.g. Chin et al. 2010, White \& Sommerville 2010). While these sharks could still be regarded as 'reef sharks', especially since encounter probability rises within $2 \mathrm{~km}$ of reefs, this study illustrates that some of these species may have broader patterns of habitat use and, on occasion, occur in habitats several kilometres away from the nearest reef. Some reef sharks may occur in these habitats when moving between different reefs, as has been demonstrated for grey reef sharks (Heupel et al. 
2010). Other reef sharks such as the lemon shark Negaprion brevirostris may use non-reef environments for extended periods (Pikitch et al. 2005, DeAngelis et al. 2008). Further exploration of the residency and movement patterns of these species and how they use different habitats could help to redefine the habitat associations of these species, their vulnerability to pressures, and their ecological roles.

Patterns of habitat use can affect the vulnerability of reef sharks and other mobile species, to human pressures and other factors. Temporary transitory movements or extended use of a range of habitats may expose the species to a wider suite of risks, with the frequency of movement and the time spent in different habitats affecting the level of exposure to risks. Coastal habitats around the world are under significant pressure from fishing, pollution, and habitat degradation, with severe impacts reported from several locations (Jackson et al. 2001, Lotze et al. 2006). Use of inshore habitats, such as coastal foreshores, mangroves, and seagrass beds, exposes these reef sharks to direct threats from fisheries and disturbance, as well as indirect effects of habitat loss and degradation. These pressures also affect coral reefs which are under pressure worldwide by pollution, habitat degradation, over-harvesting, and climate change (Hughes et al. 2003, Burke et al. 2011). Thus, the occurrence of reef sharks in coral reef and coastal and inshore environments increases their exposure to multiple fisheries, and to multiple natural and anthropogenic impacts such as habitat degradation, pollution, and disturbance.

The use of multiple habitats could also give rise to cumulative impacts and can magnify impacts when multiple life stages are exposed to pressures. For example, fishing of adult sandbar sharks Carcharhinus plumbeus in northern Western Australia (WA) between 2000 and 2005 jeopardised a hitherto sustainable fishery that harvested juvenile sandbar sharks off southwestern Australia (McAuley et al. 2007) and required prompt management intervention to significantly reduce the catch on the northern WA coast (Stobutski \& McLoughlin 2008). In the GBR, the number of reef sharks taken in the GBR net fishery is low compared to other shark species. Nevertheless, mortality from net fishing on, or near, inshore reefs could exacerbate the pressure on species such as the whitetip reef shark and grey reef shark which are already experiencing declines in the GBR (Robbins 2006, Heupel et al. 2009). Cumulative impacts may also be a concern for species such as the blacktip reef shark. This species is the third most commonly caught reef shark in the GBR coral reef line fishery, a fishery that has reportedly driven declines in other reef sharks (Robbins et al. 2006, Heupel et al. 2009). Catch composition data from Heupel et al. (2009) and commercial logbook catch data suggest that between $9230 \mathrm{~kg}$ and $9243 \mathrm{~kg}$ of blacktip reef sharks were captured in this fishery during peak landings between 2002 and 2003. The blacktip reef shark's use of shore habitats also exposes it to net fisheries which target these habitats for coastal species such as the high value barramundi Lates calcarifer. The catch composition data presented in this study and commercial fisheries landings data suggest that the GBR net fishery caught more blacktip reef sharks than the line fishery over the 2002 to 2003 period, with catches between 10857 and $13222 \mathrm{~kg}$ respectively. However, the 2 fisheries are licensed separately, and the potential cumulative impact from exposure to both fisheries has not been explicitly considered in fisheries management arrangements. Furthermore, the long-term effect on the GBRWHA population of this level of catch of juvenile blacktip reef sharks is not known.

While the use of multiple habitats by reef sharks could increase their exposure to threats and cumulative pressures, it may also reduce their vulnerability through functional redundancy. Specialisation to particular ecological niches or habitat types may increase the vulnerability of species and ecosystems such as forests (Davies et al. 2004), reef fishes (Munday 2004), and birds (Julliard et al. 2004). It follows that 'generalist' reef sharks which use multiple habitat types could be less vulnerable to pressures affecting coral reefs than coral reef specialists. However, this is only valid if these alternative habitat types can provide the same biological and ecological services that coral reefs provide for all life stages of these species. If coral reefs, or any other habitat used, provide unique and critical functions for any of a reef shark's life history stages, then loss of that habitat would negate the potential benefits gained from utilising multiple habitat types. Consequently, whether habitat generalisation reduces vulnerability depends on how reliant the species is in each of the habitats it uses as well as its exposure to pressures while it is present in each habitat type.

Understanding patterns of occurrence can help to inform management and conservation priorities. In this study, the whitetip reef shark and grey reef shark only occurred in coral reef habitats and thus are likely to be most vulnerable to reef-associated pressures that can affect the quality and availability of coral reef habitats, such as anthropogenic impacts (Hughes 2009, Burke et al. 2011), climate change (Hoegh-Guldberg et al. 2007, Veron 2008), and reef-based fisheries, which are suspected of driving reef shark declines in 
the GBR (Robbins et al. 2006, Heupel et al. 2009). In contrast, their absence from other coastal and inshore environments reduces their exposure to the GBR net fishery as net fishing rarely occurs in coral reef habitats. Therefore, management and conservation for more widely occurring species (e.g. the blacktip reef shark) should consider preservation of coastal habitats as well as interactions with coastal net fisheries and cumulative impacts from coral reef-based fisheries.

The use of a range of inshore and coastal habitats by reef sharks also prompts questions about the ecological roles these habitats play in sustaining reef shark populations. Habitats such as mangroves and lagoons have been proposed as important nursery grounds for a range of coral reef species (Mumby et al. 2004, Adams et al. 2006, Nagelkerken et al. 2008). Similarly, many coastal sharks use coastal habitats, such as seagrasses, mangroves, and intertidal shore habitats, for variety of purposes, such as nursery areas, foraging grounds, or mating or pupping (Heithaus et al. 2002, Simpfendorfer \& Heupel 2004, Knip et al. 2010). Shallow sand flats have been suggested as nursery areas for reef sharks such as lemon sharks and blacktip reef sharks (Feldheim et al. 2002, White \& Potter 2004, Wetherbee et al. 2007, Papastamatiou et al. 2009b). It is possible that reef sharks in the GBR are using these habitats for similar purposes which would further raise the importance of these habitats in sustaining intact coral reef ecosystems.

Certain factors need to be considered in interpreting the results of this study. Firstly, the presence of fishery observers may affect fisher behaviour which could affect data about the species caught, habitats fished and the fate of catch (Karp 2005). The use of gill nets to sample sharks in the GBR lagoon may also affect species composition due to the gear selecting for species of specific shape and size (Harry et al. 2011). This may account for low catches of species such as zebra sharks and rays which are less easily entangled in mesh nets, ultimately underestimating the occurrence of these species in non-reef habitats. Additionally, fishing patterns affected the spatial analysis. The observer programs were designed to collect data about normal fishing operations, so sampling effort was not evenly distributed amongst different combinations of habitat types in a fixed experimental design. This resulted in large standard errors in GLM outputs for some factor combinations due to low sample sizes. Furthermore, some factors are confounded where 2 or more factors naturally co-exist or were mutually exclusive. However, these issues do not alter the overall conclusion that reef shark encounter probabilities are relatively high in a range of inshore habitat types.
Distribution and habitat use patterns need to be carefully considered when studying mobile reef organisms and conducting risk assessments for these species. While previous work has classified reef sharks as those species listed as inhabiting coral reefs (Chin et al. 2010, Ward-Paige et al. 2010b), such classifications may be too simplistic. Chin et al. (2010) did not include the blacktip reef sharks or lemon sharks as species that occur in coastal and inshore habitats, and thus, the vulnerability assessment for this species in incomplete. Ward-Paige et al. (2010b) used SCUBA-based counts to infer trends in reef shark abundance, but many of the species considered commonly occur in non-reef environments that were not sampled by divers. In both instances, considering the occurrence of reef sharks in a wider range of habitat types would provide more complete accounts of vulnerability and trends.

With increasing concern about the status of reef sharks and the potential effects reef shark declines could have on reef ecosystems, there is a need to better understand how these species move between and use habitats. This study has shown that habitat use should be carefully considered in reef shark management and research, especially for reefs sharks that spend extended periods in, and have ecological dependencies on, non-reef habitats. Future studies using tagging and acoustic telemetry data, and those that integrate multiple data sources from different habitat types, would help to clarify the habitat use patterns and dependencies of reef sharks and help to ensure appropriate sample design, accurate interpretation of survey data, and more complete risk assessments to support the conservation and management of these species.

Acknowledgements. Many thanks to the FFRC fisheries observers (O. Bittar, J. White and A. Mapleston) for collecting observer data, and to the Queensland Government fisheries observers (DEEDI) and researchers for making their data available. We gratefully acknowledge Ms. S. Gibbs (JCU) for providing invaluable assistance in collating, coding and integrating habitat data for the spatial analyses. We also thank the GBRMPA Spatial Data Centre and DEEDI for data and the map used in Fig. 1. The authors also acknowledge and thank all the commercial fishers who voluntarily participated in the observer program, making the collection of these data possible. This project was funded by the Australian Government through the Marine and Tropical Sciences Research Facility Project 4.8.4. Material from Stanford University (Christopher Manning 2007) and the UCLA Academic Technology Services, Statistical Consulting Group was very helpful in performing the logistic regression models in R. Research was carried out under JCU Ethics Approval A1566; GBRMPA Permit \#G08/23753.1; and QDPI\&F Permit \#90091. 


\section{LITERATURE CITED}

Adams AJ, Dahlgren CP, Kellison GT, Kendall MS and others (2006) Nursery function of tropical back-reef systems. Mar Ecol Prog Ser 318:287-301

Anderson CR (2002) Elasmobranchs as a recreational resource. In: Fowler SL, Reed TM, Dipper FA (eds) Elasmobranch biodiversity, conservation and management: proceedings of an international seminar and workshop, Sabah, Malaysia, 1997, Vol 25. IUCN/SSC Shark Specialist Group, IUCN, Gland, p 46-51

Barnett R (1996) Shark fisheries and trade in east and southern Africa. In: The world trade in sharks: a compendium of TRAFFIC's regional studies, Vol 1. TRAFFIC International, Cambridge, p 329-340

Burke L, Reytar K, Spalding M, Perry A (2011) Reefs at risk revisited. World Resources Institute, Washington DC

Burnham KP, Anderson DR (2002) Model selection and multimodel inference: a practical information-theoretic approach. Springer-Verlag, New York, NY

> Chapman DD, Pikitch EK, Babcock F, Shivji MS (2005) Marine reserve design and evaluation using automated acoustic telemetry: a case-study involving coral reefassociated sharks in the mesoamerican Caribbean. Mar Technol Soc J 39:42-55

Chin A, Kyne PM, Walker TI, McAuley RB (2010) An integrated risk assessment for climate change: analysing the vulnerability of sharks and rays on Australia's Great Barrier Reef. Global Change Biol 16:1936-1953

Chin A, Reytar K, Lison de Loma T, Gerhardt K and others (2011) Status of coral reefs of the Pacific and outlook: 2011. Global Coral Reef Monitoring Network (sine loco)

Clua E, Buray N, Legendre P, Mourier J, Planes S (2011) Business partner or simple catch? The economic value of the sicklefin lemon shark in French Polynesia. Mar Freshw Res 62:764-770

Coles R, McKenzie L, De'ath G, Roelofs A, Long WL (2009) Spatial distribution of deepwater seagrass in the interreef lagoon of the Great Barrier Reef World Heritage Area. Mar Ecol Prog Ser 392:57-68

Cortés E (2000) Life history patterns and correlations in sharks. Rev Fish Sci 8:299-344

> Davies KF, Margules CR, Lawrence JF (2004) A synergistic effect puts rare, specialized species at greater risk of extinction. Ecology 85:265-271

DeAngelis BM, McCandless CT, Kohler NE, Recksiek CW, Skomal GB (2008) First characterization of shark nursery habitat in the United States Virgin Islands: evidence of habitat partitioning by two shark species. Mar Ecol Prog Ser 358:257-271

> Dulvy NK, Baum JK, Clarke S, Compagno LJV and others (2008) You can swim but you can't hide: the global status and conservation of oceanic pelagic sharks and rays. Aquat Conserv 18:459-482

Feldheim KA, Gruber SH, Ashley MV (2002) The breeding biology of lemon sharks at a tropical nursery lagoon. Proc R Soc Lond B Biol Sci 269:1655-1661

Field I, Meekan M, Speed C, White W, Bradshaw C (2011) Quantifying movement patterns for shark conservation at remote coral atolls in the Indian Ocean. Coral Reefs 30: 61-71

Fitzpatrick R, Abrantes KG, Seymour J, Barnett A (2011) Variation in depth of whitetip reef sharks: does provisioning ecotourism change their behaviour? Coral Reefs 30:569-577

Fowler SL, Cavanagh RD, Camhi M, Burgess GH and others (2005) Sharks, rays and chimaeras: the status of the chon- drichthyan fishes. Status survey. IUCN/SSC Shark Specialist Group, IUCN, Gland

Friedlander AM, DeMartini EE (2002) Contrasts in density, size, and biomass of reef fishes between the northwestern and the main Hawaiian Islands: the effects of fishing down apex predators. Mar Ecol Prog Ser 230:253-264

GBRMPA (Great Barrier Reef Marine Park Authority) (2009) Great Barrier Reef Outlook Report 2009. Great Barrier Reef Marine Park Authority, Townsville

Graham KJ, Andrew NL, Hodgson KE (2001) Changes in relative abundance of sharks and rays on Australian South East Fishery trawl grounds after twenty years of fishing. Mar Freshw Res 52:549-561

Graham NAJ, Spalding MD, Sheppard CRC (2010) Reef shark declines in remote atolls highlight the need for multifaceted conservation action. Aquat Conserv 20:543-548

Grech A, Coles RG (2010) An ecosystem-scale predictive model of coastal seagrass distribution. Aquat Conserv 20: 437-444

> Harry AV, Tobin AJ, Simpfendorfer CA, Welch DJ and others (2011) Evaluating catch and mitigating risk in a multispecies, tropical, inshore shark fishery within the Great Barrier Reef World Heritage Area. Mar Freshw Res 62: 710-721

> Heithaus M, Dill L, Marshall G, Buhleier B (2002) Habitat use and foraging behavior of tiger sharks (Galeocerdo cuvier) in a seagrass ecosystem. Mar Biol 140:237-248

Heithaus MR, Frid A, Wirsing AJ, Worm B (2008) Predicting ecological consequences of marine top predator declines. Trends Ecol Evol 23:202-210

> Heupel MR, Williams AJ, Welch DJ, Ballagh A and others (2009) Effects of fishing on tropical reef associated shark populations on the Great Barrier Reef. Fish Res 95:350-361

> Heupel MR, Simpfendorfer CA, Fitzpatrick R (2010) Largescale movement and reef fidelity of grey reef sharks. PLoS ONE 5: e9650

Hoegh-Guldberg O, Mumby PJ, Hooten AJ, Steneck RS and others (2007) Coral reefs under rapid climate change and ocean acidification. Science 318:1737-1742

Hughes TP (2009) Human impact on coral reefs. In: Hutchings $\mathrm{P}$, Kingsford MJ, Hoegh-Guldberg $\mathrm{O}$ (eds) The Great Barrier Reef: biology, environment and management. CSIRO Publishing, Collingwood, p 85-95

Hughes TP, Baird AH, Bellwood DR, Card M and others (2003) Climate change, human impacts, and the resilience of coral reefs. Science 301:929-933

Jackson JBC, Kirby MX, Berger WH, Bjorndal KA and others (2001) Historical overfishing and the recent collapse of coastal ecosystems. Science 293:629-638

Julliard R, Jiguet F, Couvet D (2004) Common birds facing global changes: what makes a species at risk? Glob Change Biol 10:148-154

Karp FW (2005) Observer sampling bias: causes, consequences and solutions. In: McVea TA, Kennelly SJ (eds) 4th International Fisheries Observer Conference. NSW Department of Primary Industries, Cronulla Fisheries Research Centre of Excellence, Sydney, p 230

> Knip DM, Heupel MR, Simpfendorfer CA (2010) Sharks in nearshore environments: models, importance, and consequences. Mar Ecol Prog Ser 402:1-11

> Lotze HK, Lenihan HS, Bourque BJ, Bradbury RH and others (2006) Depletion, degradation, and recovery potential of estuaries and coastal seas. Science 312:1806-1809

Lyle JM (1987) Observations on the biology of Carcharhinus cautus (Whitley), Carcharhinus melaopterus (Quoy and Gaimard) and Carcharhinus fitzroyensis (Whitley) from northern Australia. Aust J Mar Freshw Res 38:701-710 
Mayer D, Roy D, Robins J, Halliday I, Sellin M (2005) Modelling zero-inflated fish counts in estuaries - a comparison of alternate statistical distributions. In: Modsim 2005: International Congress on Modelling and Simulation: Advances and Applications for Management and Decision Making, Melbourne, Australia, p 2581-2587

McAuley RB, Simpfendorfer CA, Hall NG (2007) A method for evaluating the impacts of fishing mortality and stochastic influences on the demography of two long-lived shark stocks. ICES J Mar Sci 64:1710-1722

Mellors JE, McKenzie LJ, Coles RG (2008) Seagrass-watch: engaging Torres Strait islanders in marine habitat monitoring. Cont Shelf Res 28:2339-2349

- Mumby PJ, Edwards AJ, Arias-Gonzalez JE, Lindeman KC and others (2004) Mangroves enhance the biomass of coral reef fish communities in the Caribbean. Nature 427:533-536

Munday PL (2004) Habitat loss, resource specialization, and extinction on coral reefs. Glob Change Biol 10: 1642-1647

Nagelkerken I, Bothwell J, Nemeth RS, Pitt JM, van der Velde G (2008) Interlinkage between Caribbean coral reefs and seagrass beds through feeding migrations by grunts (Haemulidae) depends on habitat accessibility. Mar Ecol Prog Ser 368:155-164

Pandolfi JM, Bradbury RH, Sala E, Hughes TP and others (2003) Global trajectories of the long-term decline of coral reef ecosystems. Science 301:955-958

Papastamatiou YP, Caselle JE, Friedlander AM, Lowe CG (2009a) Distribution, size frequency, and sex ratios of blacktip reef sharks Carcharhinus melanopterus at Palmyra Atoll: a predator-dominated ecosystem. J Fish Biol 75:647-654

- Papastamatiou YP, Lowe CG, Caselle JE, Friedlander AM (2009b) Scale-dependent effects of habitat on movements and path structure of reef sharks at a predatordominated atoll. Ecology 90:996-1008

Papastamatiou YP, Friedlander AM, Caselle JE, Lowe CG (2010) Long-term movement patterns and trophic ecology of blacktip reef sharks (Carcharhinus melanopterus) at Palmyra Atoll. J Exp Mar Biol Ecol 386:94-102

Pikitch EK, Chapman DD, Babcock EA, Shivji MS (2005) Habitat use and demographic population structure of elasmobranchs at a Caribbean atoll (Glover's Reef, Belize). Mar Ecol Prog Ser 302:187-197

Pitcher CR, Doherty PJ, Anderson TJ (2009) Seabed environments, habitats and biological assemblages. In: Hutchings P, Kingsford MJ, Hoegh-Guldberg O (eds) The Great Barrier Reef: biology, environment and management. Springer, Collingwood, p 51-58

Queensland Department of Primary Industries \& Fisheries (2010) Coastal habitat resources information system (CHRISweb). Queensland Department of Primary Industries and Fisheries, Brisbane

R Development Core Team (2010) R: a language and environment for statistical computing. R Foundation for Statistical Computing, Vienna

Robbins WD (2006) Abundance, demography and population structure of the grey reef shark (Carcharhinus amblyrhynchos) and whitetip reef shark (Triaenodon obesus) Fam. Carcharhinidae. PhD thesis, James Cook University, Townsville

Robbins WD, Hisano M, Connolly SR, Choat JH (2006) Ongoing collapse of coral-reef shark populations. Curr Biol 16:2314-2319

Salini J, McAuley R, Blaber S, Buckworth R and others
(2007) Northern Australian sharks and rays: the sustainability of target and bycatch fisheries, Phase 2. CSIRO Marine and Atmospheric Research, Cleveland

> Simpfendorfer CA (2000) Predicting population recovery rates for endangered western Atlantic sawfishes using demographic analysis. Environ Biol Fishes 58:371-377

Simpfendorfer CA, Heupel MR (2004) Assessing habitat use and movement. In: Carrier JC, Musick JA, Heithaus MR (eds) Biology of sharks and their relatives. CRC Press, Boca Raton, FL

Stevens JD (1984) Life-history and ecology of sharks at Aldabra Atoll, Indian Ocean. Proc R Soc Lond B Biol Sci 222:79-106

Stevens JD, Bonfil R, Dulvy NK, Walker PA (2000) The effects of fishing on sharks, rays, and chimaeras (chondrichthyans), and the implications for marine ecosystems. ICES J Mar Sci 57:476-494

Stevenson C, Katz LS, Micheli F, Block B and others (2007) High apex predator biomass on remote Pacific islands. Coral Reefs 26:47-51

Stobutski I, McLoughlin KJ (2008) Joint authority fisheries In: Wilson D, Curtotti R, Begg G, Phillips K (eds) Fisheries status reports 2008. Department of Agriculture, Fisheries and Forestry, Canberra, p 366-367

> Teh LSL, Zeller D, Cabanban A, Teh LCL, Sumaila UR (2007) Seasonality and historic trends in the reef fisheries of Pulau Banggi, Sabah, Malaysia. Coral Reefs 26: 251-263

Tobin AJ, Simpendorfer CA, Mapleston A, Currey L and others (2010) A quantitative ecological risk assessment of sharks and finfish of Great Barrier Reef World Heritage Area inshore waters: a tool for fisheries and marine park managers: identifying species at risk and potential mitigation strategies. Marine and Tropical Sciences Research Facility, Cairns

UCLA Academic Technology Services - Statistical Consulting Group (2010) R data analysis examples: logistic regression. University of California, Los Angeles, CA

Veron JEN (2008) Mass extinctions and ocean acidification: biological constraints on geological dilemmas. Coral Reefs 27:459-472

Ward-Paige C, Flemming JM, Lotze HK (2010a) Overestimating fish counts by non-instantaneous visual censuses: consequences for population and community descriptions. PLoS ONE 5: e11722

Ward-Paige CA, Mora C, Lotze HK, Pattengill-Semmens C, McClenachan L, Arias-Castro E, Myers RA (2010b) Large-scale absence of sharks on reefs in the greaterCaribbean: a footprint of human pressures. PLoS ONE 5: e11968

Wetherbee BM, Gruber SH, Rosa RS (2007) Movement patterns of juvenile lemon sharks Negaprion brevirostris within Atol das Rocas, Brazil: a nursery characterized by tidal extremes. Mar Ecol Prog Ser 343:283-293

White WT, Kyne PM (2010) The status of chondrichthyan conservation in the Indo-Australasian region. J Fish Biol 76:2090-2117

White WT, Potter IC (2004) Habitat partitioning among four elasmobranch species in nearshore, shallow waters of a subtropical embayment in Western Australia. Mar Biol 145:1023-1032

White WT, Sommerville E (2010) Elasmobranchs of topical marine ecosystems. In: Carrier JC, Musick JA, Heithaus MR (eds) Sharks and their relatives II: biodiversity, adaptive physiology and conservation. CRC Press, Boca Raton, FL

Submitted: October 19, 2011; Accepted: March 14, 2012

Proofs received from author(s): July 16, 2012 